in general, education and the academy itself (Wallerstein 2001; Giroux 2011; Chomsky 2000). In other words, capitalism is internal to the very structure and practice of archaeology. As part of the internally related dialectical whole, archaeology is capitalism, so working within our disciplinary boundaries means that our work can only perpetuate and reproduce those structures. This is essentially why I find the question whether archaeology is conceivable with the degrowth movement more than a little problematic. If neo-liberalism (growth, capitalism, etc.) no longer existed, neither would archaeology.

And this leads me to my final point: that I think Zorzin has missed an opportunity to really contemplate what archaeology may look like in a world without capitalism (which is what degrowth is, after all). Since every aspect of archaeology is implicated in capitalist structures, archaeology would (hopefully) not exist as such in any form that we may recognize - the academy, CRM, NGOs, community organizations, etc. I do not think many of the ideas presented here are successful or satisfying, mainly because the framing is based on reified externally related entities, such as neo-liberalism and archaeology, that freeze complex dynamics and social relations. Rather than thinking about a 'golden age', in either the past or the future, that stems from facile either/ or framing, I find it more useful to think about the complexity of dialectical relations that both limit and enable action. Archaeology is capitalism but has always also been against capitalism. Archaeology has always served the nation state and thwarted it at the same time. Instead of seeing the solution in terms of a scheme of temporal stages, embracing the internal dialectical connectedness allows us to see that it is both at the same time. For me, the problem is not simply 'growth', but how to think about post-archaeological alternatives where we can participate in creating a different life, one that is not based on the logic of capitalism, one that subverts and transforms inequalities and oppression, striving for social justice and dignity for all humans, and our ability to realize the free conscious life activity that lies at the heart of our species-being.

Archaeological Dialogues (2021), 28, 28-35

doi: $10.1017 /$ S1380203821000064

\title{
Reply to comments
}

\section{Nicolas Zorzin}

I greatly appreciate that four colleagues agreed to contribute to a constructive discussion of the degrowth movement and its potential implications for archaeology. The comments proposed by the reviewers are overall rather encouraging, notwithstanding the identification of some blind spots which will need to be developed and discussed further. The discussion also brought new ideas, and in so doing, despite some disagreements on the use of terminology, highlighted the difficulty of representing ourselves clearly, and projecting that representation into capitalist organizations, collapsing capitalist societies, or a post-capitalist world. Degrowth is axiomatically defined by this progressive transition until the advent of a post-growth society. As such, it is not a dogma defining a path but a range of possibilities that make it impossible to 'contemplate what archaeology may look like' (p. 28) in the future. As I am offered this last window for answering comments, I would like to take the opportunity to clarify and extend some of the views presented in my original article.

First, a note should be added concerning the circumstances of this publication: a turning point in my relation to archaeological fieldwork occurred in the United Kingdom in 2015, following my

(C) The Author(s), 2021. Published by Cambridge University Press. This is an Open Access article, distributed under the terms of the Creative Commons Attribution-NonCommercial-NoDerivatives licence (http://creativecommons.org/licenses/by-nc-nd/4.0/), which permits non-commercial re-use, distribution, and reproduction in any medium, provided the original work is unaltered and is properly cited. The written permission of Cambridge University Press must be obtained for commercial re-use or in order to create a derivative work. 
participation in a salvage archaeology contract. It is not an overstatement to say it was a traumatic experience, and I cannot imagine how the working conditions I experienced could be physically and mentally bearable for an average human being in the long term. After reflecting on that experience and after a first phase of analytical writing (Zorzin 2016b), I decided to submit a manuscript to Archaeological dialogues, not aiming to deconstruct a specific case, but rather to propose a transition towards actions. I did so because we were collectively in desperate need, as expressed by the frustrations of my interviewees in the UK in 2015 (and my own), of tangible solutions. Yet, as Flexner underscores in his answer, without any connections between us at that stage, and with very different personal and professional experiences, we were following the same train of thought and reaching relatively similar conclusions. The synchronicity of our proposals seemed to indicate that such reflection in archaeology might be necessary, challenging and fruitful. As far as I know, the subject has been already developing, as illustrated in 2018 by the Colloque sur l'éthique en archéologie, in Paris (Pasquini and Vandevelde 2019), bringing together scholars and non-scholars. As such, degrowth did not and does not constitute a new 'academic niche', but simply represents the desire for action of many of us, often echoing our pre-existing involvement in community activism (social, ecological, etc.).

Furthermore, to define the attempt to connect the degrowth movement to archaeology, I could not have picked a better term than the one proposed by Flexner in his answer, seeing us as bricoleurs (from the French for handyman). The term carries numerous meanings, which I think illustrates particularly well our approach: a bricoleur is a person who patches things together, attempting to create something possibly useful and meaningful for the community, and potentially aesthetically satisfying or somehow provocative. Bricoler (as a verb), or bricolage (as a noun) implies a certain degree of amateurism, of learning through trial and error, and even though the concept has been regarded increasingly as futile or even as a nuisance in capitalist society, it echoes the idea of the coming of the 'age of low tech' of the French engineer Bihouix (2014). Bricoler implies a philosophy favouring modest (but meaningful, or even vital) achievements with modest means, and, through the making or the repair of artefacts, it represents the quintessence of a logic conflicting frontally with the values of the consumerist society and opposing the fetishism of new shiny and expensive gadgets. To bricoler objects or ideas is a form of decolonization, moving away from capitalistic concepts and practices. What might be an obvious routine activity for some, for many of us, in contrast, bricoler is mostly an abstraction, as we have only learned to dispose and consume. As a result, and this should not be underestimated, we need to relearn bricolage to imagine and create, and almost from scratch.

Although the explicit interconnection made by Flexner between the degrowth movement and science fiction is in fact a crucial element of the degrowth approach consisting in 'awakening the imaginaries' (Damasio 2020), I did not dare to state it as frankly as Flexner did, but I do see the future of archaeologists in a very similar way, i.e. as 'shadowy saboteurs, subverting the surveillance systems of the powerful to scavenge for valuable resources to contribute to our communities' (p. 18). Echoing Flexner's definition above, a very influential novel (not translated from French), La zone du dehors (Damasio 2009), should be mentioned here. The book also describes a dystopic colonized world hierarchized and defined by scarcity (like the 'exterminism' model of Frase (2016), introduced by Flexner), where a small community of resistants bricolent at the margin of the colony with the dumps of the consumerist core (which they hack), while attempting to establish the new basis of an anarcho-degrowth-inspired society. This is surely fiction, but it might give us a glimpse on how archaeology could play a role in a future living with the ruins of capitalism' (p. 18), as suggested by Flexner. Here, I should mention that a few months ago, a MA student I supervise (Dong-Yo Shih 施東佑) proposed writing his archaeology thesis (which I cite here with his consent) on 'Toxic heritage and contemporary archaeology. Electronic waste at Erren river' in Taiwan. To continue his research project, he proposed publishing a catalogue of the waste excavated and set up an exhibition in collaboration with both an artist and the local community. Despite some resistance among members of the archaeological community who 
consider it 'not archaeology' and threaten him with 'unemployability', this transition of the focus of our profession towards the ruins of capitalism is obviously already in motion.

Second, I am particularly thankful to Sadie Watson's detailed and honest answer, herself operating within the contract archaeology sector in the UK. Here, I would like to recontextualize the contractual constraints experienced in the UK, which explained the issue of 'participant observation' mentioned by Watson, and which illustrates further the problematic management of the mega-project in question (Zorzin 2016b). A rather peculiar arrangement, consisting in half of the contracts signed directly with the developer, placed half of the archaeological team in a position of 'mercenaries', or atomized workers. This may have aimed to discourage horizontal solidarity among workers but in fact achieved the opposite (the developer underestimated the strength of the archaeological camaraderie tradition). Yet, from our workers' perspective, this configuration placed the hierarchy in a blurry zone: was the power structure established by the developer or by the archaeological unit? Who was accountable to whom? As such, this situation forbade the development of a vertical 'spirit of solidarity' among the archaeological staff.

My proposal of 'sabotaging' some of our work might sound excessive, and wrongly directed against the archaeological unit itself. In any case, the night shift's resisting attitude was not aimed at 'sabotaging' the work of the archaeological unit or opposing its regular staff, but rather at sabotaging the takeover by the developer and opposing the working nonsense we had to deal with. As such, the incentive of this unplanned 'participant observation' was born in opposition to the abusive injunctions of the developer's contract: notably, not to discuss any topics concerning our work between us or with outsiders. This attempt at absolute control of communication unleashed a range of reactions among the staff; mine was to attempt to make public the developer's managerial abuses and manipulations. As such, I agree with Watson that this 'participant observation' might not have perfectly followed les règles de l'art because it was both impromptu and could not be announced too widely (i.e. vertically). However, a balance was reached by revealing enough in the publication to make the case relevant and understandable while protecting the anonymity of the archaeologists, and I think both aims were achieved adequately.

For such a contribution to be relevant and not to fall into the category of 'academic exercise, well-meaning but ultimately toothless' (p. 26), it is crucial that these ideas are put into action, and to that extent I agree with Wurst's critique. Yet one advantage for archaeologists that Wurst might have overlooked is that archaeology in academia gives plenty of space to implement a large range of actions on the fieldwork, which are unequivocally only possible through the coordinated actions of numerous actors. There is no such thing as individual action in modern and socially engaged archaeological fieldwork, and my intention in writing this article was not only to share and debate the potential alternative practices for archaeology, but also give myself and our future team possible guidelines to work with in developing a collegial project. The initial formulation of these ideas might have taken an individual form for now, but its transformation towards actions and solutions would only be conceivable as an anti-capitalistic community answer, including the crucial involvement of non-academics. This reflection could hopefully fulfil its potential in Greece (as mentioned before) with a long-term archaeological project where I intend to put into practice some of the ideas exposed here. Flexner and I will certainly fail in numerous ways in these collaborative and transformative attempts, but even though minimal or marginal, the little successes we will achieve should, hopefully, bring positive change.

Finally, I realized that not having developed a section dedicated to neo-liberalized academia where archaeologists are all currently trained might seem complicit with my own recent integration within academia. On that matter, I fully agree with Moshenska that the reflection should be urgently directed toward academia itself as well. To enact our degrowth lecture of archaeology's future, we will indeed have to entirely redefine our teaching and its goals in a falling or postcapitalist society. As pointed out by Moshenska, the solutions are not straightforward and contain in themselves the seeds of an unwanted gentrification or re-elitization of archaeological practices, in complete opposition to our common goals. Attempting to decolonize the content of most 
teaching is something I am seeking now. Anecdotally, but particularly relevant here, I was subsequently contacted by another department with an obscure agenda, to integrate one of my courses with their programme of 'sustainable development', a concept which I always strongly opposed, as it consists only of 'green-washing' unethical behaviours, attempting to maintain 'business as usual' and ultimately changing nothing. As such, neo-liberal academia is attempting to absorb divergent and alternative voices, branding them with trendy labels in order to optimize both visibility and recruitment, while neutralizing the initial goals of the voices challenging the capitalist order. I did not and would not comply with this.

As such, I cannot 'retreat to my ivory tower' but I must rather go back to a crumbling one. As suggested by Moshenska, despite a general rise in numbers of students, sometime increase in funds, and construction of brand-new buildings, etc., academia has entered a deep ethical and pedagogical crisis. For my colleagues and myself, a lot of time and energy would have to be dedicated to resisting, getting around or literally sabotaging what neo-liberal academia is trying to make us do against the interests of students (the tendencies are to form compliant technicians, not challenging intellectuals), against communities' interests, against research quality and publications, and against the development of a critical and meaningful future for archaeology. So far, we have not had to deal with a direct attempt to control the contents of courses or publications. However, the pressure towards such control is perceptible, notably with the acceleration of digital tracking with the COVID-19 crisis that is getting closer and closer to the context of our work. It is still possible to ignore or bypass such control, but if it becomes unavoidable and effective in curbing critical content (see the recent case of the UK with 'school guidance' forbidding the use of 'anti-capitalist material'; Busby 2020), my own moral integrity and social engagement would result in my resignation, but not before a fight necessarily involving a collective and solidary answer.

\section{References}

Aitchison, K., and D. Rocks McQueen, 2020: State of the archaeological market 2019, Federation of Archaeological Managers and Employers, https:/famearchaeology.co.uk/wp-content/uploads/2020/07/State-of-the-Archaeological-Market-2019-1.pdf.

Alexander, S., 2015: Simplicity, in G. D’Alisa, F. Demaria and G. Kallis (eds), Degrowth. A vocabulary for a new era, New York and London, 146-148.

Altman, D., 2005: Neoliberalism? It doesn't exist, New York Times, 16 July 2005, available at www.nytimes.com/2005/07/16/ business/worldbusiness/neoliberalism-it-doesnt-exist.html.

Andreucci, D., and S. Engel-Di Mauri, 2019: Capitalism, socialism and the challenge of degrowth, Capitalism nature socialism 30, 176-188.

Aparicio Resco, P. (ed.), 2016: Archaeology and neoliberalism, Madrid.

Atalay, S., 2019: Can archaeology help decolonize the way institutions think? How community-based research is transforming the archaeology training toolbox and helping to transform institutions, Archaeologies. Journal of the World Archaeological Congress 15(3), 514-535.

Bacigalupi, P., 2009: The windup girl, New York.

Bailey, R., 2018: Is degrowth the only way to save the world? Welcome to the latest gussied up version of Malthusian eco-pessimism!, Reason, 16 February 2018, at https://reason.com/2018/02/16/is-degrowth-the-only-way-to-save-the-wor.

Barca, S., 2019a: 'An alternative worth fighting for'. Degrowth and the liberation of work, in E. Chertkovskaya, A. Paulsson and S. Barca (eds), Towards a political economy of degrowth, London, 175-192.

Barca, S., 2019b: The labor(s) of degrowth, Capitalism nature socialism 30, 207-216.

Bihouix, P., 2014: L'âge des low tech. Vers une civilisation techniquement soutenable, Paris.

Black Trowel Collective, 2016: Foundations of an anarchist archaeology. A community manifesto, Savage Minds (now Anthrodendum) Decolonizing Anthropology series, at https://savageminds.org/2016/10/31/foundations-of-ananarchistarchaeology-a-community-manifesto, accessed 22 December 2020.

Bollier, D., 2014: La renaissance des communs. Pour une société de coopération et de partage, Paris.

Bourdieu, P., 1998: L'essence du néoliberalisme. Cette utopie, en voie de réalisation, d'une exploitation sans limite, Le monde diplomatique, March 1998, 3.

Brick, H., 2014: Fortune-tellers of the capitalist world, Journal of American studies 48(3), 873-878.

Brincat, S. (ed.), 2014: Communism in the 21st century, Santa Barbara, CA. 
Brownhill, L., T. Turner and W. Kaara, 2012: Degrowth? How about some 'de-alientation'?, Capitalism nature socialism 23, 93-104.

Burns, J., 2014: Across the great divide. Free markets from right to left, Modern Intellectual History 11(1), 253-265.

Busby, M., 2020: Schools in England told not to use material from anti-capitalist groups. Idea categorised as 'extreme political stance' equivalent to endorsing illegal activity, The Guardian, 27 September 2020, at www.theguardian.com/education/ 2020/sep/27/uk-schools-told-not-to-use-anti-capitalist-material-in-teaching.

Cervera-Marzal, M., 2016: Les nouveaux désobéissants. Citoyens ou hors-la-loi?, Lormont.

Chomsky, N., 2000: Chomsky on miseducation, Lanham, MD.

Chomsky, N., 2013: Le bien commun. Entretien avec David Barsamian, Montréal.

D'Alisa, G., F. Demaria and G. Kallis (eds), 2015: Degrowth. A vocabulary for a new era, New York and London.

Daly, H.E., 1993: Sustainable growth. An impossibility theorem, in H.E. Daly and K.N. Townsend (eds), Valuing the Earth. Economics, ecology, ethics, Cambridge and London, 267-273.

Damasio, A., 2009 (1999): La zone du dehors, Paris.

Damasio, A. (ed.), 2020: Le réveil des imaginaires, Socialter, hors-série.

Davis, P., 1999: Ecomuseums. A sense of place, Leicester.

Demaria, F., F. Schneider, F. Sekulova and J. Martinez-Alier, 2013: What is degrowth? From an activist slogan to a social movement, Environmental values 22, 191-215.

Elhacham, E., L. Ben-Uri, J. Grovoski, Y.M. Bar-On and R. Milo, 2020: Global human-made mass exceeds all living biomass, Nature 588, 442-444.

Escobar, A., A. Kothari, A. Salleh, F. Demaria and A. Acosta, 2019: 'Development' is colonialism in disguise. Others worlds are possible - the pluriverse is breathing, Open Democracy, at www.opendemocracy.net/en/oureconomy/developmentcolonialism-disguise/?fbclid=IwAR3Ade152MDSCyjBRofIGoXcXGlPvLzhqgRVeGxrnF0148BWrgFZKlpdK2c.

Euler, J., 2018: The commons. A social form that allows for degrowth and sustainability, Capitalism nature socialism 30(2), 1-18.

Everill P., 2009: The invisible diggers. A study of British commercial archaeology, Oxford and Exeter (Heritage Research Series 1).

Faubert, D., 2019: 'Eco-anxiety'. How to spot it and what to do about it, BBC three news, 27 March 2019, at www.bbc.co.uk/ bbcthree/article/b2e7ee32-ad28-4ec4-89aa-a8b8c98f95a5.

Fisher, M., 2009: Capitalist realism. Is there no alternative?, Ropley.

Flexner, J.L., 2018: Doing archaeology in non-state space, Journal of contemporary archaeology 5(2), 254-259.

Flexner, J. 2020: Degrowth and a sustainable future for archaeology, Archaeological dialogues 27, 159-171.

Flexner, J.L., and E. Gonzalez-Tennant, 2018: Anarchy and archaeology, Journal of contemporary archaeology 5(2), $213-219$.

Foster, J., 2011: Capitalism and degrowth. An impossibility theorem, Monthly review, January 2011, 26-33.

Fotopoulos, T., 2007: Is degrowth compatible with a market economy?, International journal of inclusive democracy 3(1), 1-16.

Frase, P., 2016: Four futures. Life after capitalism, London.

Gil, R., 2009: Breaking the silence. The hidden injuries of neo-liberal academia, in R. Flood and R. Gill (eds), Secrecy and silence in the research process. Feminist reflections, London, 228-244.

Giroux, H.A., 2011: Zombie politics and culture in the age of casino capitalism, New York.

Gorz, A., 1980: Ecology as politics, Montréal.

Gramsci, A., 1971 (1929-1935): Selections from the prison notebooks of Antonio Gramsci, New York.

Guay, J.-H., 2019: Perspective monde. Outil pédagogique des grandes tendances mondiales depuis 1945, Ecole de politique appliquée (Faculté des lettres et science humaines, Université de Sherbrooke, Québec, Canada, at http://perspective. usherbrooke.ca/bilan/servlet/BMTendanceStatPays?codeTheme=2andcodeStat=NY.GDP.MKTP.KD.ZGandcodePays= FRAandoptionsPeriodes $=$ peReEcoandcodeTheme2 $=$ 2andcodeStat $2=$ NY.GDP.MKTP.KD.ZGandcodePays2 $=$ USAandoptions DetPeriodes $=$ avecNomPandlangue $=\mathrm{fr}$.

Haagh, L., 2019: The case for universal basic income, Cambridge.

Hale, S.M., 1990: Controversies in sociology, Toronto.

Hall, S., and A. O'Shea, 2013: Common-sense neoliberalism. The battle over common sense is a central part of our political life, Soundings 55, 8-24.

Hamilakis, Y., 1999: La trahison des archéologues. Archaeological practice as intellectual activity in postmodernity, Journal of Mediterranean archaeology 12(1), 60-79.

Hamilakis, Y., 2007: From ethics to politics, in Y. Hamilakis and P. Duke (eds), Archaeology and capitalism. From ethics to politics, Walnut Creek, 15-40.

Hamilakis, Y., 2015: Archaeology and the logic of capital. Pulling the emergency brake, International journal of historical archaeology 19(4), 721-735.

Hamilakis, Y., and P. Duke (eds), 2007: Archaeology and capitalism. From ethics to politics, Walnut Creek.

Harvey, D., 2005: A brief history of neoliberalism, Oxford.

Harvey, D., 2016: Neoliberalism is a political project. An interview with David Harvey conducted by Bjarke Skaerlund Risager, Jacobin, 23 July 2016, at www.jacobinmag.com/2016/07/david-harvey-neoliberalism-capitalism-labor-crisis-resistance. 
Harvey, D., 2017: Marx, capital and the madness of economic reason, London.

Helfrich, S., and D. Bollier, 2015: Commons, in G. D'Alisa, F. Demaria and G. Kallis (eds), Degrowth. A vocabulary for a new era, New York and London, 75-78.

Högberg, A., C. Holtorf, S. May and G. Wollentz, 2018: No future in archaeological heritage management?, World archaeology 49(5), 639-647.

Hutchings, R.M., 2018: Meeting the shadow. Resource management and the McDonaldization of heritage stewardship, in B.L. Stiefel and J.C. Wells, Human-centered built environment heritage preservation. Theory and evidence-based practice, Abingdon, 67-87.

Hutchings, R.M., and M. La Salle, 2013: Five thoughts on commercial archaeology, ICHT Bulletin 2013-1, at https:// criticalheritagetourism.files.wordpress.com/2015/08/icht-bulletin-2013-1.pdf.

Hutchings, R.M., and M. La Salle, 2015: Archaeology as disaster capitalism, International journal of historical archaeology 19(4), 699-720.

Illich, I., 1980: Vernacular values, Philosophica 26, 47-102.

Jackson, T., 2017: Prospérité sans croissance. Les fondations pour l'économie de demain, 2nd edn, Louvain-la-Neuve.

Jarrige, F., 2016: Les précurseurs de la décroissance. Gravelle, Zisly et les anarchistes naturiens contre la civilisation industrielle, Neuvy-en-Champagne.

Kallis, G., 2019: Socialism without growth, Capitalism nature socialism 30, 189-206.

Kallis, G., F. Demaria and G. D’Alisa, 2015: Degrowth, in G. D’Alisa, F. Demaria and G. Kallis (eds), Degrowth. A vocabulary for a new era, New York and London, 1-17.

Kallis, G. and H. March, 2014: Imagineries of hope. The utopianism of degrowth, Annals of the Association of American Geographers 105(2), 360-368.

Kawelu, K.L., and D. Pakele, 2014: Community-based research. The next step in Hawaiian archaeology, Journal of Pacific archaeology 5(2), 62-71.

Kehoe, A.B., 2007: Archaeology within marketing capitalism, in Y. Hamilakis and P. Duke (eds), Archaeology and capitalism. From ethics to politics, Walnut Creek, 169-178.

Kempf, H., 2009: Pour sauver la planète, sortez du capitalisme, Paris.

Klein, N., 2008: The shock doctrine. The rise of disaster capitalism, New York.

La Salle, M., and R. Hutchings, 2016: What makes us squirm. A critical assessment of community-oriented archaeology, Canadian journal of archaeology/Journal canadien d'archéologie 40, 164-180.

Latouche, S., 2004: Survivre au développement. De la décolonisation de l'imaginaire économique à la construction d'une société alternative, Paris.

Latouche, S., 2015a: Decolonization of imaginary, in G. D’Alisa, F. Demaria and G. Kallis (eds), Degrowth. A vocabulary for a new era, New York and London, 117-120.

Latouche, S., 2015b: Disaster, pedagogy of, in G. D’Alisa, F. Demaria and G. Kallis (eds), Degrowth. A vocabulary for a new era, New York and London, 94-96.

Latouche, S., 2019a: Comment réenchanter le monde. La décroissance et le sacré, Paris.

Latouche, S., 2019b: La décroissance, Paris.

Latouche, S., and A. Jappe, 2015: Pour en finir avec l'économie. Décroissance et critique de la valeur, Paris.

Le Guin, U.K., 1974: The dispossessed, New York.

Levine, P.J., 1986: The amateur and the professional. Antiquarians, historians and archaeologists in Victorian England 1838-1886, Cambridge.

Lopez, G., 2017: Cornel West's attacks on Tanehisi Coates, explained, Vox, 20 December 2017, at www.vox.com/identities/ 2017/12/20/16795746/ta-nehisi-coates-cornel-west-twitter.

Louis, E. (ed.), 2014: Pierre Bourdieu, l'insoumission en héritage. Ce que la vie fait à la politique, Paris.

Lydon, C., 2017: Noam Chomsky. Neoliberalism is destroying our democracy. How elites on both sides of the political spectrum have undermined our social, political, and environmental commons (interview, 1 June 2017), The Nation, at www.thenation.com/article/noam-chomsky-neoliberalism-destroying-democracy.

McGuire, R.H., 2007: Politics is a dirty word, but then archaeology is a dirty business, in Y. Hamilakis and P. Duke (eds), Archaeology and capitalism. From ethics to politics, Walnut Creek, 9-10.

McNally, D., 2011: Global slump. The economics and politics of crisis and resistance, Oakland, CA.

Matsuda, A., and K. Okamura (eds), 2011: New perspectives in global public archaeology, New York, Heidelberg and London.

Menzies, D., and C. Wilson, 2020: Indigenous heritage narratives for cultural justice, Historic environment 32(1), 54-69.

Mirowski, P., 2014: The political movement that dared not speak its own name. The neoliberal thought collective under erasure, Institute for News Economic Thinking, Working Paper 23, September 2014.

Mirowski, P., 2018: Neoliberalism. The movement that dare not speak its name, American affairs 2(1), 118-141.

Moshenska, G. (ed.), 2017: Key concepts in public archaeology, London.

Mongeau, S. (ed.), 2007: Objecteurs de croissance. Pour sortir de l'impasse: la décroissance, Montréal.

Moore, J.W., 2017: World accumulation and planetary life, or, why capitalism will not survive until the 'last tree is cut', Progressive review 24(3), 175-202. 
Ott, H., 2019: Petit Manuel de désobéissance civile. Restons dans l'action, Yggdrasil 1, Effondrement et renouveau, 38-43. Parance, B., and J. de Saint Victor (eds.), 2014: Repenser les biens communs, Paris.

Parga-Dans, E., 2019: Heritage in danger. The collapse of commercial archaeology in Spain, Archaeological dialogues 26, 111-122.

Pascoe, B., 2018: Dark emu, Broome, WA.

Pasquini, B., and S. Vandevelde, 2019: Archéo-éthique. Colloque international à l'Institut d'histoire de l'art, mai 2018, Les nouvelles de l'archéologie 155, 52-57.

Peck J., 2013: Explaining (with) neoliberalism, Territory, politics, governance 1(2), 132-157.

Pethokoukis, J., 2017: Who needs progress anyway? Not the 'degrowth' movement, AEIdeas, 27 March 2017, at www.aei.org/ publication/who-needs-progress-anyway-not-the-degrowth-movement.

Picea Kulturav, 2020: About Picea's cultural heritage, at www.piceakulturarv.se/om-picea-kulturarv.

Piketty, T., 2019: Capital et idéologie, Paris.

Pinker, S., 2018: Enlightenment now. The case for science, reason, humanism and progress, New York.

Prádanos, L.I., 2018: Postgrowth imaginaries. New ecologies and counterhegemonic culture in post-2008 Spain, Liverpool.

Pudney, C., 2019: Instrumentalised archaeology. Cease and desist?, in H. Williams, C. Pudney and A. Ezzeldin (eds), Public archaeology. Arts of engagement, Oxford, 109-125.

Radio Open Source (Arts, ideas, and politics with Christopher Lydon), 2017: Welcome to our neoliberal world, 16 March 2017, Boston.

Rathbone, S., 2017: Anarchist literature and the development of anarchist counter-archaeologies, World archaeology 49(3), 291-305.

Redclift, M., 2005: Sustainable development (1987-2005). An oxymoron comes of age, Sustainable development 13(4), special issue, Critical perspectives on sustainable development, 212-227.

Renou, X., 2015: Disobedience, in G. D'Alisa, F. Demaria and G. Kallis (eds), Degrowth. A vocabulary for a new era, New York and London, 162-164.

Sauvé, L., 2007: La dérive et l'impasse du développement durable, in S. Mongeau (ed.), Objecteurs de croissance. Pour sortir de l'impasse: la décroissance, Montréal, 33-57.

Sayer, D., 1987: The violence of abstraction. The analytical foundations of historical materialism, Oxford.

Schlanger, N., L. Nespoulous and J. Demoule, 2016: Year 5 at Fukushima. A 'disaster-led' archaeology of the contemporary future, Antiquity 90(350), 409-24.

Schor, J.B., 2015: Work sharing, in G. D'Alisa and G. Kallis (eds), Degrowth. A vocabulary for a new era, New York and London, 195-198.

Schwartzman, D., 2012: A critique of degrowth and its politics, Capitalism nature socialism 23(1), 119-125.

Scialabba, G., 2016: Low dishonest decades. Essays and reviews, 1980-2015, Boston.

Servigne, P., and R. Stevens, 2015: Comment tout peut s'effondrer. Petit manuel de collapsologie à l'usage des générations présentes, Paris.

Shanks, M., and R.H. McGuire, 1996: The craft of archaeology, American antiquity 61(1), 75-88.

Shepperson, M., 2017: British archaeology is in fight for survival, The Guardian, 5 July 2017, at www.theguardian.com/ science/2017/jun/20/trouble-brewing-british-archaeology?CMP=share_btn_fbandfbclid=IwAR19m_ES_0ev-nprjCp0Uu cOZQYPWeiGysSEdrfb1KfUsDDa_FfOIe3NFM.

Sizaire, V., 2019: Des sans-culottes aux 'gilets jaunes', histoire d'une surenchère répressive. Maintien de l'ordre, les fauxsemblants du modèle français, Le monde diplomatique, April 2019, 4-5.

Smith, C., and G. Jackson, 2006: Decolonizing indigenous archaeology. Developments from Down Under, American Indian quarterly 30(3-4), 311-349.

Stan, D., 2007: De l'individuel au collectif. Stratégies de changement: La simplicité volontaire, in S. Mongeau (ed.), Objecteurs de croissance. Pour sortir de l'impasse: La décroissance, Montréal, 92-96.

Stiegler, B., 2019a: 'Il faut s'adapter'. Sur un nouvel impératif politique, Paris.

Stiegler, B., 2019b: 'S'adapter. Le nouvel horizon du libéralisme?', La grande table des idées, France Culture, Paris, 26 January 2019, radio broadcast, at www.franceculture.fr/emissions/la-grande-table-2eme-partie/sadapter-le-nouvel-horizon-duliberalisme.

Spratt, D., and I. Dunlop, 2019: Existential climate-related security risk. A scenario approach, breakthrough, Melbourne.

Swift, R., 2014: S.O.S. Alternatives to capitalism, Oxford.

Tanuro, D., 2013: Green capitalism. Why it can't work, London.

Thoreau, H.D., 2017 (1849): La désobéissance civile (first published as Civil disobedience), Paris.

Unti, B.J., 2018: The job guarantee and transformational degrowth, in M. Murray and M. Forstater (eds), Full employment and social justice, Cham (Binzagr Institute for Sustainable Prosperity), 63-82.

Vandevelde-Rougale, A., and N. Zorzin, 2019: De la professionnalisation à la vassalisation. L'archéologue, entre éthique professionnelle et responsabilité sociale d'entreprise, Canadian journal of bioethics/Revue canadienne de bioéthique 2(3), 109-119.

Vergara-Camus, L., 2019: Capitalism, democracy, and the degrowth horizon, Capitalism nature socialism 30, $217-233$. 
Wallerstein, I. 2001: Unthinking social science, Philadelphia.

Waterton, E., and L. Smith (eds), 2009: Taking archaeology out of heritage, Newcastle upon Tyne.

Weber, M., 2003 (1917): Le savant et le politique, tr. Catherine Colliot-Thélène, Paris.

Weiss, M., and C. Cattaneo, 2017: Degrowth. Taking stock and reviewing an emerging academic paradigm, Ecological economics 137, 220-230.

Willie, E., 2019: A Melanesian view of archaeology in Vanuatu, in M. Leclerc and J.L. Flexner, Archaeologies of Island Melanesia. Current approaches to landscapes, exchange, and practice, Canberra, 211-214.

Wright, E.O., 2005: Basic income as a socialist project, paper presented at the annual US-BIG Congress, 4-6 March 2005 (University of Wisconsin), at www.ssc.wisc.edu/ wright/Basic\%20Income\%20as\%20a\%20Socialist\%20Project.pdf.

Wurst, L.-A., 2019: Should archaeology have a future?, Journal of contemporary archaeology 6(1), 168-181.

Zorzin, N., 2010: Archéologie au Québec. Portrait d'une profession, Archéologiques 23, 1-15.

Zorzin, N., 2011a: Contextualising contract archaeology in Quebec. Political-economy and economic dependencies, Archaeological review from Cambridge 26(1), 119-135.

Zorzin, N., 2011b: The political economy of a commercial archaeology. A Quebec case-study, doctoral thesis, Faculty of Humanities, University of Southampton, at https://eprints.soton.ac.uk/344777.

Zorzin, N., 2013: The political economy of Japanese archaeology. Reflective thoughts on current organisational dynamics, Japanese journal of archaeology 1, 1-17.

Zorzin, N., 2014: Heritage management and Aboriginal people. Relations in a global economy. The contemporary challenges of Victoria (Australia), Archaeologies 10(2), 132-167.

Zorzin, N., 2015a: Archaeology and capitalism. Successful relationship or economic and ethical alienation?, in C. Gnecco and D. Lippert (eds), Ethics and archaeological praxis, New York and London (World Archaeological Congress (WAC) 1) 115-139.

Zorzin, N., 2015b: 'Dystopian archaeologies. The implementation of the logic of capital in heritage management, in C. Gnecco and A. Dias (eds), Disentangling contract archaeology, special issue of International journal of historical archaeology 19(4), 791-809.

Zorzin, N., 2016a: Economie et philosophie politique de l'archéologie préventive française. Naissance, institutionnalisation et in-corporation d'un commun, Les nouvelles de l'archéologie 146, 55-59.

Zorzin, N., 2016b: New managerial strategies in British commercial archaeology, in P. Aparicio Resco (ed.), Archaeology and neoliberalism, Madrid, 297-325.

Zorzin, N., 2017: Archaeology and development in Taiwan. The case of Hanben, AP. Journal in public archaeology 7, 21-32. 